\title{
大学専門課程一教育学部一からみた地学の現状と問題点
}

\author{
石井醇* \\ Earth Science Education and its Problem in a Faculty of Education
}

Atsushi ISHII*

\section{I. 地学教育の必要性}

雲仙普賢岳の噴火, 奥尻島の津波, 阪神大震災, 豊浜トンネルの崩落, といった近年の我が国の大 きな自然災害は, みな地学関連事象であり, その 意味では地学に対する一般の注意関心が今ほど高 まったことはかつて無かったといえる。しかし地 学は, 我々人類の様々な生活の場面に直接間接に 関係していて，単に災害予知や予防の上だけで必 要なものではない。資源開発, 気候や気象, 時刻, 太陽活動の変化に伴う影響, 構造物の建設や生活 の場としての地球の構造とその構成物, 一つの系 としての地球環境とその保全, 地球の歴史の上の 一断面である現在という視点に立つ持続可能な開 発, 等々を含む地学は, 地学関係者が予て主張し てきたことであるが, 理科の他の科目に比べ重要 性の点で決して劣るものではなく, また地学特有 の考え方・取り扱い方があるので，他の科目の中 で取り扱われて済まされるものではない。

このような地学について知識・理解や興味・関 心を持つことは, 教師はもちろん, 一般の市民ば かりでなく，企業に携わる人々，議員や政治家， そして特に為政者にとって是非必要なことである。 現在, これら多くの人々が地学についての知識 . 理解に乏しいために, 地学の重要性に気付いてい ないものと思われるからである。このように書く と, 地学のエゴを主張しているように受け取られ かねない。しかし産業革命以後現在まで, 日本を 含めた先進国の産業や経済の発展, 生活の内容や
生活の場の改造などは, それらが地球に住む人間 を含めた生物にとっての環境に及ぼす影響につい ての配慮はあまりというより殆ど成されずに，行 なわれてきた。近年ようやく地球環境の悪化が心 配され出した。

更に 21 世紀へ向かって, アジアやアフリカな どの現在発展途上の国の人々が, 今の先進国の人々 と同じような生活を実現しようとするならば，食 料, 水, 資源, エネルギー, 環境, 生活の場等々, 様々な面で大きな壁に突き当たらざるを得なくな ることが心配される。

これらの多くは地学に関連する事柄であり, 全 ての人間が少なくとも興味関心を持ち, 考慮する 必要がある事柄であると考えるのである。

それにつけても, 将来教員になるべき学生に対 する地学教育の現状は, まことに心細いものとい わざるを得ない。

\section{II. 大学教育学部の現状}

1）現行カリキュラム一東京学芸大学の例

小学校では一人の担任が全教科を担当し, 中学 校では地学分野は理科の教員の一人が担当する。 ところで地学や理科に限らず, 指導する教師がつ まらないと思いつつ指導していたり，少なくとも 面白さが分からないまま担当していて，生徒に感 銘を与えるような指導ができるとは思えない。

大学のうち, 卒業して教員になる者が多い教育 学部のカリキュラムの一例として, 筆者の勤める 東京学芸大学のものをみてみる。

* 日本地学教育学会会長・東京学芸大学

* President of Japan Society of Earth Science Education - Tokyo Gakugei University 
まず本学の課程（コース）と学生数（1 学年 1,215 名）の概略を説明すると, 教員養成課程の 教育系（835名）と教員以外の道に進む者を養成 する教養系（380名）から成る。さらに教育系は, 小学校教員養成課程 (A 類と略称 510 名), 中学 校教員養成課程 (B 類 145 名), 障害児教育教員 養成課程 ( $\mathrm{E}$ 類 40 名), 特別教科教員養成課程 ( $\mathrm{D}$ 類, 高等学校一数学, 理科, 音楽, 美術·工 芸, 保健体育, 書道一各 20 名, 計 120 名), 幼稚 園教員養成課程（C類 20 名）から成る。

そして教養系は, 国際文化教育課程（K類 90 名), 人間科学課程 ( $\mathrm{N}$ 類 140 名), 情報環境科学 課程 ( $\mathrm{J}$ 類 100 名), 芸術課程 ( $\mathrm{G}$ 類 50 名) であ る。

この内, 理科を選修・専攻する者 (理科生と仮 称する）は, A 類の 80 名, B 類の 15 名, $\mathrm{D}$ 類の 20 名, 合計 115 名と, $\mathrm{J}$ 類の内の 20 名前後であ る。

なお，この内で地学科に所属する者は $\mathrm{A}$ 類が 20 名前後, B 類が $0 \sim 3$ 名, $\mathrm{D}$ 類が $5 \sim 8$ 名, J 類 が 0 ～名, 1 学年平均 30 名である。

カリキュラムは課程毎に多少の違いがある。主 に教育系についてみてみる。

卒業のための履修基準単位は, $\mathrm{B}$ 類, $\mathrm{C}$ 類, $\mathrm{D}$ 類および教養系の各課程は 124 単位, A 類は 130 単位, $\mathrm{E}$ 類は 147 単位となっている。

これらの内, 22 単位は共通科目で, 広い教養を 身につけることを期するもので, 全ての課程に共

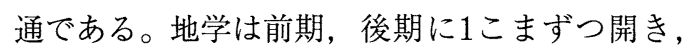
それぞれ, 天文, 地球物理, 岩石鉱物, 地質古生 物の 4 人が 3 週ずつ順に担当する。選択者は変動 が大きいが 250〜 400 名で, 1 学年のおよそ20 35 パーセントといったところである。

教育系では教職科目を履修しなければならない が, これはA類では 43 単位, $\mathrm{E}$ 類の小免コースで は 44 単位, $\mathrm{B}$ 類, $\mathrm{D}$ 類では 20 単位, $\mathrm{E}$ 類の中免 コースでは 24 単位, C 類では 37 単位となってい る。

この内 $\mathrm{A}$ 類, $\mathrm{C}$ 類と, $\mathrm{E}$ 類の小免コースでは理 科教育法を 2 単位, $\mathrm{B}$ 類および $\mathrm{D}$ 類では理科生の み理科教育法を 2 単位履修する。
専攻科目は課程によって履修単位が異なり，ま た科目も大きく異なっている。

$\mathrm{A}$ 類では，45 単位のうち，16〜19 単位は自選 修以外の小学校の各教科の教材研究を修得しなけ ればならない。その中で, 理科生以外の者では理 科教材研究を 2 単位履修する。理科生は選修科目 として 24 単位理科の科目を履修するが, 地学の 科目としては, 地学科所属でない者は地学実験 2 単位を含む 4 単位だけで, それ以外は選択科目と して 2 4 単位を半数程の者が履修する程度であ るので, 非理科生に比べればいくらか地学を履修 しているが，決して多いとはいえない。地学科所 属の学生は他に地学の科目を 8 単位履修し, さら に卒業研究 4 単位がある。

$\mathrm{B}$ 類では専攻科目は 62 単位で, 理科専攻生の 内, 地学選修以外の学生は, 地学に関しては地学 実験を含む 8 単位履修する。地学生は他に地学の 科目を 26 単位と卒業研究 4 単位を履修する。

D 類については省略する。

あとは, 非理科生では自由選択 20 単位の内,

もし選択すれば理科の科目からも取れるが，一般 には履修者はあまりいない。

結局, A 類の非理科生では, 理科に関する単位 は「理科教育法 2 単位, 理科教材研究 2 単位」合 計わずか 4 単位である。この中で地学に関するも のは, 物理, 化学, 生物, 地学がそれぞれ平等に 取り上げられているとしても四分の一, すなわち 1 単位程度ということになる。

これに共通科目として地学に関するものを選択 する者（20３5パーセント程度）は 2 単位プラス することになる。

さらに自由選択科目として地学の科目を取れぱ その分プラスになる。

また B 類の理科生についても, 地学選修以外の 学生は, 地学の科目 8 単位と理科教育法 2 単位の 中の地学に関する部分である。

ところで, 高等学校で地学を履修してきた学生 は, 正確に統計をとったわけではないが, 時々挙 手させてみたところによると，およそ一割程度と 思われる。

以上のような本学のカリキュラムや高等学校で 
の地学の履修状況を考え合わせると, 本学の小学 校教員養成課程を卒業する非理科生の九割程度の 者の地学に関する知識・理解は, 中学校時代の理 科で修得したものに, 本学での理科教育法・教材 研究の中で地学に関するものがいくらか補強され た程度といえる。それ以上を修得している者は， 理科生を含めても二割程度ではなかろうか。

\section{2）志望者の傾向}

本学入学者, その中で特に理科生に聞いてみる と, 本来理系志望というよりは文系志望であった という者がかなりいる。なぜ理科を受けたか問う と, 高校の進路指導で教員養成学部へは文系志望 者を向けるためである, ということであった。ど のくらいの割合かは定かでないが, 高校の進路指 導ではそのような傾向がいくらかはあることも事 実のようである。

\section{III. 地学の特質・教員採用状況}

\section{1）地学の特質}

地学で取り扱われる内容は, 地球の内部から宇 宙まで，しかもそれらの発生から未来へかけての 変化の過程つまり経過であって, 人類を含めた地 球上の生物の継続的な生存のための知識と理解を 多くの人に得てもらうことが狙いであろうと思わ れる。

具体的には, 地形, 岩石鉱物, 地質古生物, 地 震, 気象, 天体宇宙等々多岐にわたり, しかもこ れらは多少の講義を受けて知識は得ても, 現物を 前にしたり，現地に行くと戸惑ってしまったりす る場合が多い。ところがこれらは, 実際に現地で 体験し体感してみて始めてそれぞれの意義を知り, 面白さがわかるものが多い。このような面がある ので, 多くの小学校教員や中学校の地学専攻でな い理科教員にとっては, 生徒に興味を持たせるよ うに地学を指導することは簡単ではないものと思 われる。

\section{2) 教員採用状況}

東京都では児童生徒数の減少に伴って，次第に 教員採用数を減らしてきた。小学校教員のこの春 (平成 8 年) の採用予定数は 50 名（志願者数は 1,971名であり, 実際の合格者数は補欠も含めて
148 名であったが）となってしまった。本学の小 学校教員養成課程の 1 学年定員が 510 名である ことを考えれば，この採用数がいかに深刻なもの であるかわかる。

また中学校教員もこの春の採用予定数は 100 名 であり，実際の合格者は補欠も含めると 389 名と かなり増員されたとはいえ，志願者数が 2,981 名 であったことを考えると，これもまたなかなか厳 しい数字である。

東京都における高等学校の地学の教員にいたっ ては,ここ 10 年ばかり採用試験すら行なわれて いない。そのため地学の教員の年齢がどんどん高 くなって, 中・高年ばかりになってしまっている。 高等学校においても物理, 化学, 生物と共に地 学もぜひ開設し, バランスのとれた理科教育を進 めるべきではなかろうか。

一方小・中・高等学校の教員の採用については, 各教育委員会の意向・権限もあるが, それよりも それぞれの学校での科目その他についての教員の 構成を考慮して各学校長が決定するのが普通のよ うである。そうであるとすれば，地学教育にとっ ては都道府県の教育委員と共に各学校長の持つ自 然観・地球観, 地学についての知識や理解の内容 と程度が重要な意味を持ってくる。我が国民に健 全な自然観・地球観を育成する上で, 小・中・高 等学校での理科教育が果たす役割は大きいはずで あり, その教育に当たる小・中・高等学校の教師 として, 健全な自然観・地球観を持つ者を採用す ることこそ重要である。

\section{IV. 改 善 策}

\section{1）教員採用について}

健全な自然観・地球観を持った生徒を育てるた めには, 各教科・科目の間のバランスが大切で, 各校の教員を採用し補充する際にはこの観点で行 なって欲しいと願うものである。

それには都道府県の教育委員並びに小・中・高 等学校の校長の理解を期待するものである。

ところで, 小学校では 35 人あるいはそれ以下 の学級がかなり多くなっている様子であるが, 中 学校では未だ 40 人学級が半数ちかく残っている。 
特に国立大学附属校では 40 人学級が厳しく守ら れている。保護者の転勤に伴う転校生を, 定員を 超えて受け入れることさえ求められている。

近年, 不登校やいじめ等の問題が各地の学校, 特に中学校で頻発し, 関係者ばかりでなく多くの 人が心を痛めている。また, これからの学校教育 には, 個性を尊重し個に応じた教育がますます求 められよう。

これらに十分対応するには現場の教師にとって は体がいくつあっても足りないであろう。

このように現場の教員には, 勤務時間の上から もまた勤務内容の点でも, もっとゆとりが与えら れてしかるべきではなからうか。

少子化に伴い教員採用数の絞り込みが全国的に 進んでいて教員志望の卒業生の就職が困難になっ てきているが，これを機に是非学級規模を見直し， 各校の教員の充実を図って欲しい。

\section{2) 教員養成課程の充実}

繰り返しになるが, 次のように考えれば地学の 大切さが理解されるのではなかろうか。

人間は子女に教育の機会を与えるが，これは人 間社会で生きていくための知識とルールと技術を 修得させ, 文化を受け継がせさらに発展させるた めであろう。

ところで, 人間が生活しているのは地球表層部 であり，そこで生存し続けるためにはこの地球表 層部についての知識とルールを学び, そこで生活 する技術を身につけなければならないことは当然 で, それらを可能にさせるのが地学であり地学教 育ではなからうか。

ところが前述のとおり, 学校での地学教育はま ことに心細いものである。

そこで教員養成課程では, 教師の素養としての 地学を少なくとも数単位修得させるべきではなか ろうか。

しかし現実には本学の場合, カリキュラムが変 更されて未だ 4 年目であり，これをすぐまた変え ることは困難である。またこのカリキュラムから
学生の選択に任せる部分が大幅にふえた。このよ うな状況下で全学生に地学を数単位履修させるこ とはなかなか難しく, 差し当たってはせいぜい多 くの学生に選択されるよう努める他はない。

これからの，21世紀へかけての教員に求められ る資質や能力は, 各教科についての深い知識と指 導力はもちろん, 学級経営の手腕, 生徒の個性に 応じたきめ細かな適切な指導ができること，時に は登校不適応生やいじめに対するカウンセリング 的対応，等々多岐にわたる。

このような資質や能力を持った教員を，これま でのような 4 年間の養成課程で育てることは容易 ではない。

そこでこの際，教育は百年の計と悟り，上述の ような優れた教員は 4 年プラス修士課程 2 年, あ るいは一貫 6 年制の課程を設けて養成すべきでは なかろうか。教科科目や教育実習を充実させ，力 ウンセリングの方法等も修得し，卒業論文や修士 論文の他に 2 年次あたりで課題研究に取り組む等, 自ら課題を見出しそれを解決する姿勢・態度を養 いその手法を身につけることで，21 世紀に生きる 生徒を指導することができるようになろう。

\section{3）教員研修の制度と機会の充実}

前述のような教員養成制度が発足した場合，現 職の教員が自己の資質・能力を新しい制度の終了 者と同等に高めたいと望む場合には, 大学院等で 研修し，同じ資格が修得できる様な制度を設けた い。その場合特に大切なことは，その教員が研修 に出ても勤務校が困らないような教員の配置が保 証されることである。

このように資格を高めたい場合だけでなく，こ れからの時代には世の中の様々な面において変化・ 進歩が大変早くなり, 教員も卒業以後, 絶えず新 しいことを学び続ける必要があるとおもわれるが, 何年か毎に研修会などに参加して, リフレッシュ 教育を受けることができるような制度も欲しい。

以上現状と問題点そして改善策について, 思い つくままに述べさせていただいた。 